\title{
Relationship between Internet Addiction, Gaming Addiction and School Engagement among Adolescents
}

\author{
İbrahim Taş \\ Department of Educational Sciences, Bulent Ecevit University, Turkey
}

Copyright $\bigcirc 2017$ by authors, all rights reserved. Authors agree that this article remains permanently open access under the terms of the Creative Commons Attribution License 4.0 International License

\begin{abstract}
This research examined the relationship of Internet addiction and gaming addiction with school engagement and effects of Internet addiction and gaming addiction on school engagement. The research was conducted with 365 students (140, 38.4\%, males; 225, $61.6 \%$, females) studying at an Anatolian high school in Gaziantep province. Personal Information Form, Scale of Internet Usage Addiction, Gaming Addiction Scale for Adolescents and School Engagement Scale for Children and Adolescents (High School Form) were utilized as data collection tools. The data obtained were analyzed with correlation and multiple regression analysis. A weak negative relationship was found between Internet addiction and school engagement. No relationship was found between gaming addiction and school engagement. It was also concluded that Internet addiction is a significant predictor of school engagement and gaming addiction does not predict school engagement significantly.
\end{abstract}

Keywords Adolescence, Internet Addiction, Gaming Addiction, School Engagement, Multiple Regression

\section{Introduction}

Nowadays, Internet comes across as a tool for communication, entertainment, academics and social connection that can be easily accessed by every individual. Meeting so many needs has made Internet a must for humankind. Adolescents who go through a very problematic process due to their developmental attributes are the risk group in Internet addiction and gaming addiction. In addition to the period-specific problems experienced by adolescents going on their academic lives, possible Internet and gaming addictions may cause problems at school and in their school-related behaviors.

It is observed that one of the prominent characteristics of Internet for adolescents is academic usage while the other one is recreational usage [1]. There are some attractive elements to the online world. The online world being an output area for implicit feelings of individuals which they have not managed to express before, an environment in which they can explore the new aspects of their identity, a critical source of new friendship, offering the chance to hide their identity whenever they wish [2], offering a free world beyond the boundaries of the physical world, involving no hierarchy, and having an innovative structure [3] are some of the factors that make Internet attractive for people from every walk of life. Having a very broad coverage cause Internet usage to rise very quickly. A drastic incline is observed in the usage rates between 2000 and 2017. The rates in question have been $8.503 \%$ in Africa, $1.595 \%$ in Asia, $527 \%$ in Europe, $2.137 \%$ in Latin America, 4.374\% in Middle East, 196\% in North America, $269 \%$ in Australia, and $976 \%$ across the world. As for the Internet usage areas across the world, 2017 data show that $31.2 \%$ of Africa, $46.7 \%$ of Asia, $80.2 \%$ of Europe, $62.4 \%$ of Latin America, $58.7 \%$ of Middle East, $88.1 \%$ of North America, and $69.6 \%$ of Australia use Internet. $51.7 \%$ of world population use Internet [4]

Such intensive usage brings certain problems along. Long-term and uncontrolled usage of Internet may lead to physical, psychosocial, cognitive, and developmental problems [5]. Other Internet addiction-related problems include insomnia, nutritional problems (not eating for a long time), and deterioration in school and working life [6]. As maladaptive usage of Internet may cause psychological problems, there is a drastic increase in the number of studies on effects of Internet on mental health [7].

It is seen that technological developments reshape children's and youngsters' lives [8]. Yet, it is also observed that such reshaping turns out to be negative. Quick popularity of Internet usage among youngsters [9] has brought about Internet addictions' possibility of being a danger for them [10]. Youngsters with tendency of Internet addiction may experience academic issues as well as mental and social problems [11]. Adolescence is an importance period in which several changes occur both physically and mentally. Identity development and individualization may bring along certain risks [12]. The fact that adolescents have not become mature yet makes 
them more vulnerable to addictions than adults [11].

Internet addiction was defined by Young [13] as an impulse-control problem which does not involve intoxication. Griffiths [14] defined technological addictions including Internet addiction as non-chemical behavioral addictions which also involve human-machine interaction. Behavioral addiction can be described as deterioration of individual's functionality and non-adaptation due to abnormal and frequent exhibition of a given behavior [15].

Young et al. [16] address Internet addiction in five categories: cybersex addiction, cyber-relationship addiction, net compulsions, information overload, and computer gaming addiction. Furthermore, they described symptoms of Internet addiction as preoccupation with Internet, increased anxiety when offline, hiding the amount of time when being online or lying about time, and dysfunction in life in general. Shapira et al. [17] refers to a "problematic Internet use". They defined problematic Internet use as using Internet in an uncontrolled way and having a consequent dysfunction in daily life. Dysfunction in daily life involves dysfunction of daily tasks, discharge of responsibilities also in academic and working life.

There has been a drastic increase in number of studies conducted on Internet addiction and adolescents. These studies provide enlightening information about to what extent Internet addiction is common among adolescents and the problems related to Internet addiction. Kuss et al. [9] explored that $99.8 \%$ of the adolescents access Internet at home or school and $3.7 \%$ of them describe themselves as potential Internet addicts. Cao and $\mathrm{Su}[6]$ found that $88 \%$ of the adolescents use Internet and $2.4 \%$ of them meet the addiction criteria. Moreover, behaviors such as hyperactivity, emotional problems, psychosis, neurosis and lying were found to be significantly higher among Internet addicts. Luciano [18] found in a study conducted with 200 adolescents that $71(35.5 \%)$ of them were intensive Internet users. It was concluded in the study that insecurity, family problems, school problems, poor social life, and economic problems are the factors which lead to increased use of internet. Ko et al. [19] applied scales to adolescents at intervals of 6-12-24 months and found that $10.8 \%$ of them were Internet addicts. Doğan [20] found the Internet addiction rate of $12-18$-age group to be $12.6 \%$. a positive relationship was also determined between Internet addiction and smoking. Esen [21] determined that 3.28\% of the adolescents in the study were Internet addicts. Çalışgan [22] concluded that elementary school students who use Internet for 21 hours and longer tend to be internet addicts. Ko et al. [23] found that adolescents who are aggressive towards others also have Internet addiction and these adolescents use Internet more than 2 hours a week. A positive relationship was found in a study conducted with Korean youngsters between Internet addiction and depression and suicidal thoughts [24]. Savc1 and Aysan [25] found that there is a weak positive relationship between
Internet addiction and compulsive attachment, indifferent attachment, fearful attachment, and agreement and conflict while being moderately and positively related to negative affection. A weak negative relationship was also found between Internet addiction and secure attachment, protection, intimacy, help and positive affection. Gholamian et al. [26] explored a positively significant relationship between Internet addiction among high school students and depression, anxiety and stress.

Game is a phenomenon that has been accompanying the humankind throughout the history of humanity. Games move individuals away from routines of the daily life, entertaining them and contributing to their relaxation. An important function of games is that they prepare children for responsibilities of adulthood. Qualities of games have also started to change with the popular use of Internet. Web-based, multiplayer online games and simulation games are some of the games offered by the Internet world to the mankind [27]. It is observed that the biggest problem regarding the shift of games to electronic environments is gaming addiction [28]. Young et al. [16] addressed computer gaming addiction as a category of Internet addiction. It is seen in the studies that intensive use of Internet is rather related to games and entertainment [29]. Gaming addiction can be defined as intensive game playing to the extent that it affects health, academic life and daily life while it is also described as how a gamer cannot stop playing a game, does think about games all the time and is constantly interested in games [30].

Lack of standardized criteria to define Internet addiction in a clear way [31] has brought along the Internet addiction and certain related debates. Yet, Internet gaming addiction is about to be freed from such uncertainty. Diagnostic and Statistical Manual of Mental Disorders (DSM V) listed Internet gaming addiction in Section III. This means that the diagnostic will be officially included in DSM following sufficiently supporting studies [32]. DSM V used certain diagnostic criteria for Internet gaming addiction. These nine criteria include preoccupation or obsession with Internet games, withdrawal symptoms when not playing Internet games, playing games for increasing amounts of time, failing to curb playing games, giving up on other activities for games, continuing overuse of games even with the knowledge of its negative impacts, lying to family members, therapists/counselors, or others about gaming, using games to relieve negative emotions, and putting at risk and opportunity regarding education or profession or losing ab important relationship or job [27].

Despite limited number of studies on gaming addiction, it can be said that there has been an increase in such studies recently. While Young [2] states that Internet addiction may lead to online gaming addiction, Kuss et al. [9] found that online gaming increases the risk of addiction at $2.3 \%$. Alaçam [33] concluded that the most frequent activity performed by Internet-addicted students is gaming. Kuss et al. [34] found that one of the biggest predictors of Internet 
addiction is gaming addiction. Ko et al. [35] showed that addictions are developed in online games at the most. In addition, gaming addition was found to be positively related to depressive mood, feelings of insignificance and guilt, major depression [27]; shyness and internet addiction [36]; aggression [37]; aggression and narcissism [38]; depression, low academic achievement and behavioral problems [39], and negatively related to self-control [38].

Excessive Internet use cause and playing interactive games cause academic problems. Situations such as failure to prepare for exams, to do homework given instead of exams; taking low grades, and even getting suspended from the school [13] are the negative aspects of technological addictions reflecting on the school life. Given the negative impacts of Internet and gaming addictions on academic life, it can be said that both concepts affect the concept of school engagement negatively. The concept of school engagement can be addressed as a structure that involves positive student behaviors such as continuity, participation and effort at school and students' psychological connections with their school circle [40]. Students with higher levels of school attachment have lower rates of exhibiting negative behaviors such as dropping out, absenteeism or behavioral problems in general [41].

It is seen in the literature that Internet addiction deteriorates school life [6], creates negative situations in works and transaction regarding the school [42], is related to school problems [18], is related to teachers who leave bad marks at school [43], causes problems in academic life [44], causes low academic performance [45, 46], leads to decreased grade point average [47], and Internet gaming addiction is positively related to low academic performance [39], causes students to neglect school lessons [48], and hinders doing homework [49].

The literature shows that Internet addiction and gaming addiction are related to adolescents' school life. However, it is observed in the studies that effects of Internet addiction and gaming addiction on academic achievement are investigated with only one question in general. No extensive study on effects of Internet addiction and gaming addiction on adolescents' school engagement has not been carried out. Thus, studies to be performed in this field are of importance. Accordingly, this study examined the relationship of Internet addiction and gaming addiction among adolescents with school engagement and effects of Internet addiction and gaming addiction on school engagement. To this end, answers to the following questions were sought for:

- Is there a relationship between Internet addiction and school engagement among adolescents?

- Is there a relationship between gaming addiction and school engagement among adolescents?

- Do Internet addiction and gaming addiction affect school engagement?

\section{Method}

\subsection{Research Model}

This research examining the relationship between Internet addiction, gaming addiction and school engagement among adolescents used the survey model. As the relationship between two or more variables are examined without intervention with the variables [50], this is a correlational research study.

\subsection{Research Population and Sample}

The research population is the adolescents studying at high schools in Gaziantep province. The sample was composed of 365 adolescents studying at an Anatolian high school in Gaziantep in the academic year of 2016-2017. $225(61.6 \%)$ of the students are female and $140(38.4 \%)$ of them are male. $77(21.1 \%)$ of the students were attending the ninth grade, $67(18.4 \%)$ were attending the tenth grade, $201(55.1 \%)$ were attending the eleventh grade, and 20 $(5.5 \%)$ were attending the twelfth grade. Table 1 shows students' socio-demographics.

Table 1. Sample Distribution Statistics

\begin{tabular}{|c|c|c|c|}
\hline Variable & Value & $\mathrm{f}$ & $\%$ \\
\hline \multirow{4}{*}{ Gender } & Female & 225 & 61.6 \\
\cline { 2 - 4 } & Male & 140 & 38.4 \\
\cline { 2 - 4 } & Total & 365 & 100 \\
\hline \multirow{4}{*}{ Grade } & 9 & 77 & 21.1 \\
\cline { 2 - 4 } & 10 & 67 & 18.4 \\
\cline { 2 - 4 } & 11 & 201 & 55.1 \\
\cline { 2 - 4 } & 12 & 20 & 5.5 \\
\cline { 2 - 4 } & Total & 365 & 100 \\
\hline
\end{tabular}

\subsection{Collection and Analysis of the Data}

The data were collected by interviewing the students and applying the scale forms to them in the high school selected according to the accessibility criteria. The students were briefed about importance of the study and asked to answer the items sincerely in the interview. They were also told that they did not have to provide credentials. Data were collected from 376 participants in total. 11 of the data were not subjected to the analysis because they were incomplete. The analysis was performed with 365 data. For performing a multiple regression analysis, data of dependent variable need to have a normal distribution, there cannot be any auto-correlation, and there cannot be any multiple relation problem between independent variables [51]. It was seen that these criteria were met, so the multiple regression and correlation analyses were conducted for the data analysis. The analyses were carried out in SPSS 22 software package. 


\subsection{Data Collection Tools}

\subsubsection{Personal Information Form}

The personal information form prepared by the research covers the variables such as students' socio-demographics and academic achievement, parental attitude, and duration of Internet use.

\subsubsection{Scale of Internet Usage Addiction}

Students' levels of Internet addiction were assessed using the Computer Addiction Scale for Adolescents developed by Ayas et al. [52]. The scale consists of two factors including 54 items. The first factor is composed of 28 items with factor loads varying between .512 and .795 . Explaining $29.49 \%$ of scale's total variance, this factor is called "Internet usage addiction." 5-point Likert type grading was used for scoring in the scale. The grading is provided with the choices of "always", "mostly", "often", "sometimes", and "scarcely". Cronbach's Alpha internal consistency coefficient was calculated for reliability of the scale and found to be 96 .

\subsubsection{Gaming Addiction Scale}

The scale developed by Lemmens, Valkenburg and Peter (2009) was adapted to Turkish language by Ilgaz [53]. The scale consists of 7 factors and 21 items. 5-point Likert type grading was used for scoring in the scale. The grading is provided with the choices of "never", "scarcely", "sometimes", "often" and "very often". For testing the construct validity of the scale, first- and second-level confirmatory factor analyses were performed, and it is seen that first-level factor analysis fit indexes provided good results $\quad\left[x^{2} \quad(165, \quad \mathrm{~N}=265)=271.01, \quad \mathrm{P}<0.000\right.$, RMSEA $=0.049, \mathrm{~S}-\mathrm{RMR}=0.046$, GFI $=0.91$, AGFI $=0.88$, $\mathrm{CFI}=0.99$, NNFI=0.98, IFI=0.99]. Second-level factor analysis also provided good results $\left[x^{2} \quad(179\right.$, $\mathrm{N}=265)=331.68, \quad \mathrm{P}<\quad 0.000, \quad \mathrm{RMSEA}=0.057$, $\mathrm{S}-\mathrm{RMR}=0.051, \quad \mathrm{GFI}=0.89, \quad \mathrm{AGFI}=0.86, \quad \mathrm{CFI}=0.98$, $\mathrm{NNFI}=0.98$, IFI $=0.98$ ]. Cronbach's Alpha value of the scale was found to be 0.92 [53].

\subsubsection{School Engagement Scale for Children and Adolescents (High School Form)}

The scale developed by Hill (2015) is composed of 15 items and three factors (teacher, friend, and school engagement). Higher scores obtained in the 5-point Likert type scale means higher school engagement. The scale was adapted into Turkish by Savi Çakar and Karataş [54]. Confirmatory factor analysis (CFA) was performed for construct validity of the scale. Fit indexes of the model obtained in the CFA were examined and Chi-square value $\left(\mathrm{x} 2=281.65, \mathrm{sd}=87, \mathrm{x}^{2} / \mathrm{sd}=3.23, \mathrm{p}=0.00\right)$ was found to be significant. The fit indexes were found to be RMSEA $=.09$, $\mathrm{NFI}=.90, \mathrm{CFI}=.93, \mathrm{IFI}=.93, \mathrm{RFI}=.90, \mathrm{GFI}=.90$, $\mathrm{AGFI}=.83, \mathrm{NNFI}=.91$, and $\mathrm{SRMR}=.07$, respectively. Due to higher RMSEA value than .08, $\mathrm{t}$ values and the suggestions at the end of the CFA were examined and item
6 was omitted from the analysis to perform another CFA with 14 items. Fit indexes of the model obtained in the second CFA were examined and Chi-square value $\left(\mathrm{x}^{2}=\right.$ $\left.220.87, \mathrm{sd}=74, \mathrm{x}^{2} / \mathrm{sd}=2.98, \mathrm{p}=0.00\right)$ was found to be significant. The fit indexes were found to be RMSEA $=.08$, $\mathrm{NFI}=.92, \mathrm{CFI}=.94, \mathrm{IFI}=.94, \mathrm{RFI}=.90, \mathrm{GFI}=.90$, $\mathrm{AGFI}=.85$, NNFI $=.93$, and $\mathrm{SRMR}=.06$, respectively. In the reliability analysis, Cronbach's Alpha internal consistency coefficient was found to be .91 , the split-half reliability coefficient was found to be .80 for the first half and .74 for the second half.

\section{Findings}

\subsection{Descriptive Statistics}

Table 2 shows the statistical data regarding the dependent and independent variables $(\bar{X} ; \mathrm{sd})$.

Table 2. Descriptive Statistics of dependent and Independent Variables $((\bar{X} ; \mathrm{sd})$

\begin{tabular}{|c|c|c|c|}
\hline Variables & $\bar{X}$ & SD & N \\
\hline School Attachment & 43.23 & 11.54 & 365 \\
\hline Internet Addiction & 54.64 & 20.35 & 365 \\
\hline Gaming Addiction & 37.59 & 14.59 & 365 \\
\hline
\end{tabular}

In Table 2, it is seen that values of arithmetic mean and standard deviation regarding the dependent and independent variables were found as follows: arithmetic mean $(\bar{X}: 43.23)$ and standard deviation (sd: 11.54) of adolescents' levels of school engagement, arithmetic mean $(\bar{X}: 54.64)$ and standard deviation (sd: 20.35) of their Internet addiction levels, and arithmetic mean $(\bar{X}: 37.59)$ and standard deviation (sd: 14.59) of their gaming addiction levels.

\subsection{Findings Regarding the First Research Question}

Pearson's Correlation Analysis was performed in accordance with the question "Is there a relationship between Internet addiction and school engagement among adolescents?" and the results are shown in Table 3.

Table 3. Relationship between Internet Addiction, Gaming Addiction and Psychological Symptoms

\begin{tabular}{|c|c|c|c|}
\hline Variables & $\begin{array}{c}\text { School } \\
\text { Attch. }\end{array}$ & Internet Add. & Gaming Add. \\
\hline $\begin{array}{c}\text { School } \\
\text { Attachment }\end{array}$ & 1 & & \\
\hline $\begin{array}{c}\text { Internet } \\
\text { Addiction }\end{array}$ & $-.186^{* *}$ & 1 & \\
\hline $\begin{array}{c}\text { Gaming } \\
\text { Addiction }\end{array}$ & -.011 & $.338^{* *}$ & 1 \\
\hline
\end{tabular}

It is seen in Table 3 that there is a weak negative relationship between school engagement and Internet addiction among adolescents $(\mathrm{r}=-.186, \mathrm{p}<.01)$. No relationship was found between gaming addiction and 
school engagement $(r=-.011, p>.01)$. A moderate positive relationship was explored between Internet addiction and gaming addiction $(\mathrm{r}=.338, \mathrm{p}<.01)$.

\subsection{Findings Regarding the First Research Question}

Results of the regression analysis regarding the prediction of school engagement among adolescents by Internet addiction and gaming addiction are presented in Table 4.

It is seen in Table 4 that Internet addiction and gaming addiction explain school engagement among adolescents weakly significantly $\left(\mathrm{R}=.194, \mathrm{R}^{2}=.037 . \mathrm{p}<.01\right)$. Both variables together explain about $4 \%$ of total variance in school engagement. According to the standardized regression coefficient ( $\beta$ ), the relative order of importance of the predictor variables for school engagement is Internet addiction and gaming addiction, respectively. As for the coefficients, it is seen that only Internet addiction is a significant predictor of school engagement. t-test results concerning the significance of the regression Gaming addiction is not a significant predictor. The following is the regression equation regarding the prediction of school engagement according to the regression analysis results:

SCHOOL ENGAGEMENT $=47.866+-.116 \quad$ INT . ADD.+.046 GAME

\section{Conclusions}

This research aims to investigate the effects of adolescents' Internet addiction and gaming addiction levels on their school engagement levels. The relationship between Internet addiction, gaming addiction and school engagement was also examined in the research.

The first sub-problem of the research was whether there was a relationship between Internet addiction and school engagement among adolescents. Accordingly, a weak negatively significant relationship was found between Internet addiction and school engagement levels of the adolescents. This finding means that school engagement levels decrease as Internet addiction increases. No studies have been observed in the literature to examine the relationship between Internet addiction and school engagement. On the other hand, it is possible to find studies in the literature that investigate the relationship between
Internet addiction and school achievement, school problems, and academic achievement. This finding of the study accordingly coincides with the studies in the literature ([46] Çetinkaya, 2013; [43] Tanriverdi, 2012; [18] Luciano 2010; [47] Taçyıldız, 2010; [6] Cao and Su, 2006; [42] Kubey, Lavin and Barrows, 2001; [44] Young, 1999; [45] Young and Rogers, 1998). The fact that adolescents spend so much time on Internet may cause health problems such as insomnia, fatigue, and physical disorders as well as prevent them from discharging several school responsibilities such as continuing the school, doing homework, studying for lessons and preparing for exams. It can be said that such situations may wreck the positive mood at school and decrease students' levels of school engagement.

The second sub-problem of the research was whether there was a relationship between gaming addiction and school engagement among adolescents. No relationship was found between gaming addiction and school engagement at the end of the research. No studies have been observed in the literature to examine the relationship between gaming addiction and school engagement. Nevertheless, there are certain studies concluding that gaming addiction can lead to failure at school and hindrance to lessons ([49] Taylan, Kara and Durğun, 2017; [39]Brunborg, Mentzoni and Froyland, 2014; [48] Işçibaş̧, 2011). Gaming can also be considered a socializing tool for adolescents. Students create social environments at school about the games they play and exchange information about the game strategies. Such cases may explain why this finding of the study was achieved to be irrelevant.

The third sub problem of the research was whether Internet addiction and gaming addiction have an impact on school engagement. At the end, it was concluded that Internet addiction is a significant predictor of school engagement weakly negatively and gaming addiction does not predict school engagement significantly. No studies on whether Internet addiction and gaming addiction predict school engagement have not been observed in the literature. Yet, there are studies concluding that academic achievement is a significant predictor of Internet addiction [46] Çetinkaya, 2013; [47]Taçyıldız, 2010). Given the relationship between Internet addiction and school and school-related problems in the studies conducted with adolescents, significant impact of Internet addiction on school engagement can be better understood.

Table 4. Results of Multiple Regression Analysis on Prediction of School Engagement among Adolescent

\begin{tabular}{|c|c|c|c|c|c|c|c|}
\hline Variable & $\mathrm{B}$ & Standard Error B & $\beta$ & $\mathrm{t}$ & $\mathrm{P}$ & Dual $\mathrm{r}$ & Partial R \\
\hline Constant & 47,866 & 2,006 & & 23,857 & .000 & & \\
\hline Internet Addiction & -.116 & .031 & -.205 & $-3,747$ & .000 & -.186 & -.193 \\
\hline Gaming Addiction & .046 & .043 & .058 & 1,065 & .287 & -.011 & .056 \\
\hline \multicolumn{7}{|c|}{$\begin{array}{c}\mathrm{R}=.194 \\
\mathrm{R}(2,362)=7.042 \\
\mathrm{R}^{2}=.037 \\
\mathrm{p}=.001\end{array}$} \\
\hline
\end{tabular}


Consequently, it was explored in this study that there is a weak negative relationship between Internet addiction and school engagement and Internet addiction is a significant predictor of school engagement; there is no significant relationship between gaming addiction and school engagement and gaming addiction is not a significant predictor of school engagement.

According to the results of the study, some suggestions have been made to experts working in the field. In consideration of the relationship between Internet addiction and school engagement, Internet addiction levels can be lowered through studies to be conducted with adolescents and psycho-educational programs. Reducing the Internet addiction may have a positive impact on school engagement levels. With social and cultural activities to be held in the school, the school can be made attractive to students. These activities may prevent the emergence of problems not connecting to the school. With parent's education, families can be informed about internet addiction and attachment to the school. Thus, families can be provided with the necessary precautions about internet addiction. Teachers can be informed about the relationship between these concepts. By this way teachers can be encouraged to make the school more attractive for students so that they are not to be addiction to the internet.

Some suggestions were made to researchers. No studies have been observed in the literature with regard to the relationship between internet addiction, game addiction and attachment to the school. Increasing the number of studies that examine the relationship between these concepts would contribute to the literature.

The research has some limitations. The study is limited to 365 adolescents (high school students). The study can be conducted in larger and more different samples (e.g. primary school students, secondary school students and university students).

\section{REFERENCES}

[1] Ko, C. H., Yen, J. Y., Yen, C. F., Chen, C. S. \& Chen, C. C. (2012). The Association Between Internet Addiction and Psychiatric Disorder: A Review of the Literatüre. European Psychiatry, 27, 1-8.

[2] Young, K. (1997). What Makes the Internet Addictive. http://www.icsao.org/fileadmin/Divers_papiers/KYoung-int ernetaddiction4.pdf adresinden 25.10.2015 tarihinde erilișmiștir.

[3] Güzel, M. (2006). Küreselleşme, İnternet ve Gençlik Kültürü. Küresel İletişim Dergisi 1, 1-16.

[4] Internet World Stats. (2017). Internet use statistics. 19.10.2017 tarihinde http://www.internetworldstats.com/stats.htm. Adresinden alınmıştır.

[5] Balkaya Çetin, A. \& Ceyhan, A.A. (2014). Ergenlerin internette kimlik denemeleri ve problemli internet kullanım davranışlar1. Addicta: The Turkish Journal on Addiction, 1(2). 5-46. Doi: 10.15805/addicta.2014.1.2.063.

[6] Cao, F. \& Su, L. (2006). Internet addiction among chinese adolescents: Prevalence and psychological features. Child: Care, Health and Development, 33(3), 275-281.

[7] Beranuy, M., Oberst, U., Carbonell, X. \& Chamarro. (2009). Problematic internet and mobile phone use and clinical symptoms in college students: The role of emotional intelligence. Computers in Human Behavior, 25, 11821187.

[8] Kalkan, M. \& Kaygusuz, C. (2013). Internet Bă̆ımlılı̆̆ı. Ankara: Anı Yayıncilık.

[9] Johansson, A. \& Götestam, G. (2004). Internet Addiction: Characteristics of a Questionnaire and Prevalence in Norwegian Youth (12-18 Years). Scandinavian Journal of Psychology, 45, 223-229.

[10] Kuss, D. j., Rooij, A. J. V., Shorter, G. W., Griffiths, M. D. \& Mheen, D. V., (2013). Internet addiction in adolescents: Prevalence and risk factors. Computers in Human Behavior 29, 1987-1996.

[11] Berber Çelik, C.. (2016). İnternet bağımlılı̆̆1 eğilimini azaltmada eğitsel bir müdahale. Addicta: The Turkish Journal on Addictions, 3(3), 365-386. DOI 10.15805/addicta.2016.3.0021.

[12] Çelik, G., Tahiroğlu, A. \& Avcı, A. (2008). Ergenlik döneminde beynin yapısal ve nörokimyasal değişimi. Klinik Psikiyatri, 11, 42-47.

[13] Young, K. S. (1996). Internet Addiction: Emergence of a new clinical disorder. CyberPsychology and Behavior, 1(3), 237-244.

[14] Griffiths, M. (2000). Does Internet and Computer "Addiction" Exist? Some Case Study Evidence. Cyber Psychology \& Behavior, 3(2), 211-218.

[15] Döner, C. (2011). İlköğretim öğrencilerinde internet bağımlılı̆̆ının farklı değişkenlere göre incelenmesi, Yayımlanmamıș Yüksek Lisans Tezi, Ankara, Ankara Üniversitesi Eğitim Bilimleri Enstitüsü.

[16] Young, K., Pistner, M., O'mara, J. \& Buchanan, J. (1999). Cyber disorder: The mental health concern for the new millennium. Cyber Psychology \& Behavior, 2(5), 475-479.

[17] Shapira, N. A., Goldsmith, T. D., Keck, P. E., Khosla, U. M. \& McElroy, S. L. (2000). Psychiatric features of individuals with problematic internet use. Journal of Affective Disorders, 57, 267-272.

[18] Luciana, R.P. (2010). One minute more: Adolescent addiction for virtual world. Procedia Social and Behavioral Sciences, 2, 3706-3710.

[19] Ko, C. H., Yen, J. Y., Chen, C. S., Yeh, Y. C. \& Yen, C. F. (2009). Predictive values of psychiatric symptoms for internet addiction in adolescents. Arch Pediatr Adolesc Med, 163(10), 937-943.

[20] Doğan, A. (2013). Internet bağımlılı̆̆ yaygınlığl, Yayımlanmamış Yüksek Lisans Tezi, İzmir, Dokuz Eylül Üniversitesi Eğitim Bilimleri Enstitüsü.

[21] Esen, E. (2010). Ergenlerde internet bă̆ımlılı̆̆ını yordayan 
psiko-sosyal değişkenlerin incelenmesi, Yayımlanmamış Yüksek Lisans Tezi, İzmir, Dokuz Eylül Üniversitesi Eğitim Bilimleri Enstitüsü.

[22] Çalışgan, H. (2013). Illköğretim ögrrencilerinde internet bă̆ımlılı̆̆ ve siber zorbalık, Yayımlanmamış Yüksek Lisans Tezi, İstanbul, Yeditepe Üniversitesi Sosyal Bilimler Enstitüsü.

[23] Ko, C. H., Yen, J. Y., Liu, S. C., Huang, C. F \& Yen, C. F. (2009). The associations between aggressive behaviors and internet addiction and online activities in adolescents. Journal of Adolescent Health, 44, 598-605.

[24] Kim, K., Ryu, E., Chon, M. Y., Yeun, E. J.,Choi, S. Y., \& Nam, B. W. (2006). Internet addiction in Korean adolescents and its relation to depression and suicidal ideation: A questionnaire survey. International Journal of Nursing Studies, 43, 185-192.

[25] Savc1, M. \& Aysan, F. (2016). Bağlanma stilleri, akran ilişkileri ve duyguların internet bağımlılı̆̆ını yordamadaki katkılar1. Addicta: The Turkish Journal on Addictions, 3(3) 401-432. DOI:10.15805/addicta.2016.3.0028.

[26] Gholamian, B., Shahnazi, H. \& Hassanzadeh, A. (2017). The prevalence of internet addiction and its association with depression, anxiety, and stress, among high school students. Int J Pediatr, 5(4), 4763-4770.

[27] Sürer Adanır, A., Doğru, H. \& Özatalay, E. (2017). Oyuna adanmıs bir yaşam: Bir olgu sunumu üzerinden internet oyun oynama bozukluğuna kısa bir bakış. Türk Aile Hek. Derg, 20(2), 85-90.

[28] Ayas, T. \& Horzum, M.B. (2017). Teknolojinin olumsuz etkileri. Ankara: Vize Yayıncılık.

[29] Karaca, M.(2007). Aileyi Tehdit Eden Yeni Bir Tehlike: Sanal İlisskiler. e-Journal of New World Sciences Academy, 2(3), 131-143

[30] Horzum, M.B. (2011). İlköğretim öğrencilerinin bilgisayar oyunu bağımlılık düzeylerinin çeșitli değişkenlere göre incelenmesi. Ĕgitim ve Bilim, 36(159), 56-68.

[31] Tao, R., Huang, X., Wang, J., Zhang, H., Zhang, Y. \& Li, M. (2009). Proposed Diagnostic Criteria for Internet Addiction. Addiction, 105, 556-564.

[32] Griffiths, M.D., Kuss, D. \& Pontes, H.M. (2016). A brief overwiev of internet gaming disorder and its treatment. Australian Clinical Psychologist, 2(1), 2-12.

[33] Alaçam, H. (2012). Denizli bölgesi üniversite öğrencilerinde internet bă̆ımlılı̆̆ının görülme sıklı̆̆ ve yetișkin dikkat eksikliği hiperaktivite bozukluğu ile ilişkisi, Yayınlanmamış Uzmanlık Tezi, Denizli, Pamukkale Üniversitesi, Tıp Fakültesi Psikiyatri Anabilim Dalı.

[34] Kuss, D.J., Griffiths, M.D \& Binder, J.F. (2013). Internet addiction in students: Prevalence and risk factors. Computers in Human. Behavior, 29, 959-966.

[35] Ko, C.H., Hsiao, S., Liu, G.C., Yen, J.Y., Yang, M.J. \& Yen, C.F. (2010). The characteristics of decision making, potential to take risks, and personality of college students with internet addiction. Psychiatry Research, 175, 121-125.

[36] Ayas, T. (2012). The relationship between internet and computer game addiction level and shyness among high school students. Educational Sciences Theory \& Practice, 12(2), 632-636.

[37] Çankaya, G. \& Ergin, H. (2015). Çocukların oynadıkları oyunlara göre empati ve saldırganlık düzeylerinin incelenmesi. Hacettepe University Faculty of Health Sciences Journal, 1, 283-297.

[38] Kim, E.J., Namkoong, K., Ku, T. \& Kim S.J. (2008). The relationship between online game addiction and aggression, self-control and narcissistic personality traits. European Psychiatry, 23, 212-218

[39] Brunborg, G.S., Mentzoni, R.A. \& Froyland, L.R. (2014). Is video gaming, or video game addiction, associated with depression, academic achievement, heavy episodic, drinking, or conduct problems? Journal of Behavioral Addictions, 3(1), 27-32, DOI: 10.1556/JBA.3.2014.002.

[40] Önen, E. (2014). Öğrencinin okula bağl1lığ ortaokul ve lise öğrencileri için uyarlama çalışması. Türk Psikolojik Danışma ve Rehberlik Dergisi, 5(42), 221-234.

[41] Sağlam, A. \& İkiz, F.E. (2017). Ortaokul öğrencilerinin şiddet eğilimleri ile okula bağllık düzeyleri arasındaki ilișkinin incelenmesi. Elementary Education Online, 16(3), 1235-1246.

[42] Kubey, R.W., Lavin, M.J \& Barrows, J.R (2001). Internet use and collegiate academic performance decrements: Early findings. Journal of Communication, 366-382.

[43] Tanrıverdi, S. (2012). Ortä̈ğretim öğrencelerinde internet ba ̌̆ımlılı̆̆ ile algılanan sosyal destek arasındaki ilişkinin incelenmesi, Yayımlanmamış Yüksek Lisans Tezi, Van, Yüzüncü Y1l Üniversitesi Eğitim Bilimleri Enstitüsü.

[44] Young, K. (1999). Internet addiction: Symptoms, evaluation and treatment. Innovations in Clinical Practice, 7, $\mathrm{http}: / /$ netaddiction.com/articles/symptoms.pdf adresinden 25.10.2015tarihinde erilişmiştir.

[45] Young, K. S. \& Rogers, R.C. (1998). The relationship between depression and internet addiction. Cyber Psychology \& Behavior, 1(1), 25-28.

[46] Çetinkaya, M. (2013). Ilköğretim öğrencilerinde internet bağımlılığının incelenmesi, Yayımlanmamıs Yüksek Lisans Tezi, İzmir, Dokuz Eylül Üniversitesi Eğitim Bilimleri Enstitüsü.

[47] Taçyıldız, Ö. (2010). Lise öğrencilerinin internet bağımlılı̆̆ düzeylerinin bazl değişkenlere göre yordanmasl, Yayımlanmamıș Yüksek Lisans Tezi, İzmir, Ege Üniversitesi Sosyal Bilimler Enstitüsü.

[48] Işçibaş1, Y. (2011), "Bilgisayar, İnternet ve Video Oyunları Arasında Cocuklar", Selçuk Üniversitesi İletişim Fakültesi Akademik Dergisi, 7(1), 122-130.

[49] Taylan, H.H., Kara, H.Z. \& Durğun, A. (2017). Ortaokul ve lise öğrencilerinin bilgisayar oyunu oynama alışkanlıkları ve oyun tercihleri üzerine bir araştırma. Pesa International Journal of Social Studies, 3(1), 78-87.

[50] Büyüköztürk, S.., Kılıç, Cakmak, E., Akgün, Ö.E., Karadeniz, Ş. \& Demirel, F. (2010). Bilimsel araştırma yöntemleri. Ankara: Pegem Akademi.

[51] Kalayc1, Ș. (2014). Spss uygulamalı çok değişkenli istatistik teknikleri. Ankara: Asil Yayınları. 
[52] Ayas, T., Balta, Ö. \& Horzum, M.B. (2011). Ergenler için bilgisayar bağımlılığı ölçeği. Kastamonu Eğitim Dergisi, 19(2), 439-448.

[53] Ilgaz, H. (2015). Adaptation of game addiction scale for adolescents into Turkish. Elementary Education Online, $14(3), 874-884$.
[54] Savi Cakar, F. \& Karataş, Z. (2014). Ergenlerin okula bağlanmalarının yordayıcıları olarak benlik saygısı, okul öfkesi ve yaşam doyumu. $5^{\text {th }}$ International Conferences on New Trends in Education and Their Implications, ICONTE-2014, Antalya -Türkiye 'de sözel bildiri olarak sunulmuștur. 